\title{
Preliminary Evaluation of the Characteristics of Nuclear Wastes Relevant to Geologic Isolation in Basalt
}

G. J. McCarthy

M. W. Grutzeck

May 1978

Prepared for the United States

Department of Energy

Under Contract EY-77-C-06-1030

\section{Rockwell International}

Atomics International Division Rockwell Hanford Operations 


\section{DISCLAIMER}

This report was prepared as an account of work sponsored by an agency of the United States Government. Neither the United States Government nor any agency Thereof, nor any of their employees, makes any warranty, express or implied, or assumes any legal liability or responsibility for the accuracy, completeness, or usefulness of any information, apparatus, product, or process disclosed, or represents that its use would not infringe privately owned rights. Reference herein to any specific commercial product, process, or service by trade name, trademark, manufacturer, or otherwise does not necessarily constitute or imply its endorsement, recommendation, or favoring by the United States Government or any agency thereof. The views and opinions of authors expressed herein do not necessarily state or reflect those of the United States Government or any agency thereof. 


\section{DISCLAIMER}

Portions of this document may be illegible in electronic image products. Images are produced from the best available original document. 


\author{
PRELIMINARY EVALUATION OF THE \\ CHARACTERISTICS OF NUCLEAR WASTES \\ RELEVANT TO GEOLOGIC ISOLATION IN BASALT
}

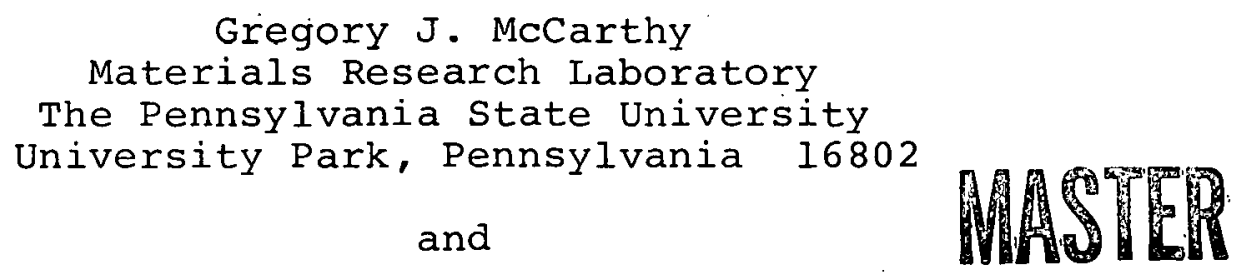

Michael W. Grutzeck

Waste Isolation Program

Rockwell Hanford Operations

Atomics International Division

Rockwell International

Richland, Washington 99352

May 1, 1978

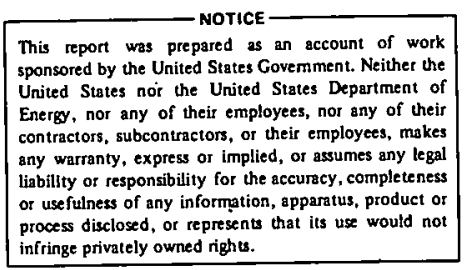

Prepared for Rockwell Hanford Operations,

A Prime Contractor to U. S. Department of Energy,

Under Curliál Number EY-77-C-06-1030

This report was prepared as an account of work sponsored by. the United States Government. Neither the United States, nor the United States Department of Energy, nor any of their employees, nor any of their cuntsaclors, subcontractors, or their employees, makes any warranty, express or implied, or assumes any legal liability or responsibility for the accuracy, completeness, or usefulness of any information, apparatus, product or process disclosed, or represents that its use would not infringe privately owned rights. 


\section{A B S T R A C T}

The physical and chemical characteristics of radioactive waste which have bearing upon the concept of geologic storage in basalt are reviewed and discussed. Ëach class of waste form ispent unreprocessed fuel, calcine, glass, and eupercaloine) has its owr unique characteristics which may or may not affect the concept of final storage of radioactive waste in basalt. These characteristios form the basis for scientific evaluation of the relative merits of oaoh of the wastelbasalt pairs. 


\section{TABLE OF CONTENTS}

$\underline{\text { Page }}$

INTRODUCTION

NUCLEAR WASTE FORMS

THERMODYNAMIC STABILITY AÑ STRUCTURAL STATE

CHEMICAL COMPOSITION

HISTORY OF WASTE FORM

LEACHABILITY

11

MISCELLANEOUS FACTORS

DISCUSSION

SPENT UNREPROCESSED FUEL

CALCINE

GLASS

SUPERCALCINE

21

CONCLUSIONS

27

ACKNOWLEDGMENTS

REFEREINCES

28

DISTRIBUTION

\section{LIST OF TABALES}

TABLE I PROPERTIES OF RADIOACTIVE WASTE FORMS

TABLE II COMPOSITIONS OF POTENTIAL COMMERCIAL REPROCESSING HIGH-LEVEL WASTE CALCINES

TABLE III COMPOSITION OF BATTELLE-NORTHWEST GLASS 76-68

TABLE IV FIXATION PHASES FOR HIGH-LEVEL WASTE CONSTITUENTS IN SUPERCALCINE

TABLE $V$ COMPOSITION OF SUPERCALCINE SPC-2 


\begin{tabular}{|c|c|c|c|c|}
\hline & & & & age \\
\hline \multirow[t]{3}{*}{ FIGURE } & 1 & $(A)$. & $\begin{array}{l}\text { SCHEMATIC REPRESENTATION FOR THE RELATIVE } \\
\text { FREE ENERGIES OF THREE SOLID FORMS OF“THE } \\
\text { SAME CHEMICAL COMPOSITION }\end{array}$ & 9 \\
\hline & . & (B) & $\begin{array}{l}\text { SCHEMATIC REPRESENTATION OF THE ACTIVATION } \\
\text { ENERGY BARRIER FOR A THERMODYNAMICALLY } \\
\text { FAVORABLE REACTION FOR EACH OF THE THREE } \\
\text { SOLID FORMS }\end{array}$ & $\therefore$ \\
\hline & & (C) & $\begin{array}{l}\text { PHASE DIAGRAM FOR THE SYSTEM A-H }{ }_{2} \text { W WHERE } \\
\text { A HAS TWO POLYMORPHIC FORMS AND } \alpha \text { AND } \beta\end{array}$ & 9 \\
\hline FIGURE & 2 & $\begin{array}{l}\text { POR? } \\
\text { CALC }\end{array}$ & $\begin{array}{l}\text { IION OF THE X-RAY DIFFRACTOGRAM OF SUPER- } \\
\text { CINE SPC- } 2\end{array}$ & 26 \\
\hline
\end{tabular}




\section{INTRODUCTION}

NUCLEAR WASTE FORMS

The present emphasis in the United States' Terminal Storage Program is not to reprocess spent fuel elements. Due to this directive, we are considering spent unreprocessed fuel to be our prime radioactive waste form to be stored in a potential basalt cavern.

If the decision were made to reprocess spent fuel with its resultant high-level waste stream, a vitrification process yielding a glass, product would probably be the leading contender for the solid waste form, since it has, to date, received the majority of research and development funding. However, calcine has not been ruled out by many investigators and a number of "advanced alternatives" to glass have received some attention.

In order to insure the comprehensiveness of our current waste/basalt interaction studies, we have chosen to include the following waste forms in our experiments: spent unreprocessed fuel; calcine; glass; and, supercalcine. The emphasis in our program during fiscal year 1977 was on glass, since, at that time, it was the leading high-level waste form candidate.

As a first step in analyzing the physical and chemical effects of storing nuclear waste in an underground basalt repository, one must first deal with the waste forms themselves. Needless to say, each waste form has its own set of unique characteristics (chemical and radiological composition, mineralogy, structure, thermal energy, etc.) which will have a direct bearing upon the storage concept. 
Fortunately, much of this information is already available in the literature. Battelle-Northwest recently compiled data through 1975 on all aspects of the back-end of the nuclear fuel cycle. 1 A recent publication ${ }^{2}$ updates some of the concepts concerning advanced waste forms and also includes an in-depth discussion of the factors governing waste/basalt interaction. Rather than duplicate these efforts once again, we are viewing these reports as a foundation for the discussion which follows. To help achieve this end, we are also including, as Table $I$, a summary table adapted from a recent U. S. Nuclear Regulatory Commission Report. ${ }^{3}$ spent unreprocessed fuel has been added to the table in an effort to be comprehensive. Since data on spent unreprocessed fuel are sparse, approximate values were sometimes assigned using the assumption that spent unreprocessed fuel is composed of nearly 96-97 weight percent of the various isotopes of uranium and, since data on uranium oxide are commonly available, these data would reflect actual spent unreprocessed fuel characteristics. When these approximations were made, they were so noted on Table I.

The purpose of the present document is to review waste form characteristics and to discuss the relevancy of these characteristics upon the concept of storage of nuclear waste in basalt.

THERMODYNAMIC STABILITY AND STRUCTURAL STATE

The structural state of the components of a waste form is an important and not widely appreciated parameter governing its reactivity. Consider the case of a 
PROPERTIES OF RADIOACTIVE WASTE FORMS (ADAPTED FROM NUREG-0279)

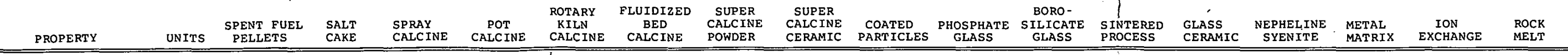

\begin{tabular}{|c|c|c|c|c|c|c|c|c|c|c|c|c|c|c|c|c|c|c|}
\hline & & & & & & & & & & & & & & & & & & \\
\hline $\begin{array}{l}\text { SoLUT ION } \\
\text { RATE }\end{array}$ & $\frac{\mathrm{mg}}{\mathrm{m}^{2} \sec }$ & $\begin{array}{l}10^{-2} \\
\text { to-5. } \\
10^{-5}\end{array}$ & $\begin{array}{l}0^{3} \\
\text { to } \\
10^{6}\end{array}$ & $\begin{array}{l}10 \\
\text { to } \\
100 \\
\end{array}$ & $\begin{array}{r}10 \\
\text { to } \\
100 \\
\end{array}$ & $\begin{array}{l}10 \\
\text { to } \\
100\end{array}$ & $\begin{array}{l}10 \\
\text { to } \\
100\end{array}$ & $\begin{array}{l}10^{-6} \\
\text { to } \\
10^{-4} \\
\end{array}$ & $\begin{array}{l}10^{-7} \\
\text { to } \\
10^{-5} \\
\end{array}$ & $\begin{array}{l}10^{-6} \\
\text { to } \\
0.01 \\
\end{array}$ & $\begin{array}{l}10^{-5} \\
\text { to } \\
0.7 \\
\end{array}$ & $\begin{array}{l}10^{-5} \\
\text { to } \\
0.01 \\
\end{array}$ & $\begin{array}{l}100^{-5} \\
\text { ito } \\
0.01 \\
0.01\end{array}$ & $\begin{array}{l}100^{-5} \\
\text { to } \\
10^{-3} \\
\end{array}$ & $\begin{array}{l}10^{-5} \\
\text { to } \\
0.7 \\
\end{array}$ & $\begin{array}{c}10^{-5} \\
10^{-5} \\
10^{-2}\end{array}$ & $\begin{array}{l}0.001 \\
\text { to } \\
0.01 \\
\end{array}$ & $\begin{array}{c}10^{-5} \\
\text { to } \\
0.01 \\
\end{array}$ \\
\hline $\begin{array}{l}\text { CORROSTIN } \\
\text { TO CLAD } \\
\text { MATERIAL }\end{array}$ & $\mathrm{nm} / \mathrm{sec}$ & * & $\begin{array}{l}\substack{\mathfrak{c} \\
\mathrm{t}_{4} \\
10^{4}} \\
\end{array}$ & $\begin{array}{l}0 \\
\text { to } \\
10\end{array}$ & 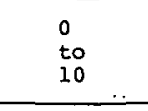 & $\begin{array}{l}0 \\
\text { to } \\
10\end{array}$ & $\begin{array}{l}0 \\
\text { to } \\
10\end{array}$ & $\begin{array}{c}0 \\
\text { to } \\
10 \\
10\end{array}$ & $\begin{array}{l}\begin{array}{c}0 \\
\text { to } \\
10\end{array} \\
\text { D. }\end{array}$ & $\begin{array}{l}0 \\
\text { to } \\
10\end{array}$ & $\begin{array}{l}0 \\
\text { to } \\
10\end{array}$ & $\begin{array}{c}0 \\
\text { to } \\
10 \\
\end{array}$ & $\begin{array}{l}0 \\
0 \\
\text { to } \\
10\end{array}$ & $\begin{array}{c}0 \\
\text { to } \\
10 \\
\end{array}$ & $\begin{array}{c}0 \\
\text { to } \\
10 \\
\end{array}$ & $\begin{array}{c}0 \\
\text { to } \\
10 \\
\end{array}$ & $\begin{array}{c}0 \\
\text { to } \\
10 \\
\end{array}$ & NA \\
\hline $\begin{array}{l}\text { RESTIDUAL } \\
\text { NITRARER } \\
\text { ANDPOR } \\
\text { WATER }\end{array}$ & 8 & $<.005$ & $\begin{array}{c}0.20 \\
\text { to } \\
30 \\
\end{array}$ & $\leq 4.0$ & $\leq 0.05$ & $\leq 4.0$ & $\leq .03$ & $\begin{array}{l}0.005 \\
\text { to } \\
0.05 \\
\end{array}$ & $\begin{array}{l}0.005 \\
\text { to } \\
0.01 \\
\end{array}$ & $\begin{array}{l}0.005 \\
\text { to } \\
0.05 \\
\end{array}$ & $\begin{array}{l}0.005 \\
\text { to. } \\
0.05\end{array}$ & $\begin{array}{l}0.005 \\
\text { to } \\
0.05 \\
\end{array}$ & $\begin{array}{l}0.005 \\
\text { to. } \\
0.05\end{array}$ & $\begin{array}{l}0.005 \\
\text { to } \\
0.05 \\
\end{array}$ & $\begin{array}{l}0.005 \\
\text { to } \\
0.05\end{array}$ & $\begin{array}{l}0.005 \\
\text { to } \\
0.05\end{array}$ & $\begin{array}{l}0.005 \\
\text { to } \\
0.05\end{array}$ & $\leq 10.0$ \\
\hline 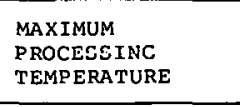 & ${ }^{{ }^{\mathrm{K}}}$ & NA & $\begin{array}{c}310 \\
\text { to } \\
720 \\
\end{array}$ & 970 & 695 & $\begin{array}{l}870 \\
\text { to } \\
1,070 \\
\end{array}$ & $\begin{array}{l}670 \\
60 \\
1,070 \\
\end{array}$ & $\begin{array}{l}1,370 \\
\text { to } \\
1,570\end{array}$ & $\begin{array}{l}1,370 \\
1,5 \% \\
1,570 \\
\end{array}$ & 1,670 & 1,170 & $\begin{array}{l}1,270 \\
\text { to } \\
1,670\end{array}$ & $\begin{array}{l}1,235 \\
\text { ito } \\
\text { it. } 370\end{array}$ & 1,270 & 1,620 & 1,470 & 1,670 & 1,000 \\
\hline $\begin{array}{l}\text { RUTHENIUM } \\
\text { VOALATLIIIRD } \\
\text { AT PROCESSTNG }\end{array}$ & 8 & NA & $\leq 1.0$ & $\leq 1.0$ & $\begin{array}{l}5 \\
10 \\
30 \\
\end{array}$ & $\therefore 1.0 \quad \mathrm{I}$ & Incignificant & $t \leq 7.0$ & $\leq 5.0$ & $\leq 10.0$ & $\begin{array}{c}3= \\
\text { to } \\
15\end{array}$ & $\leq 2.0$ & 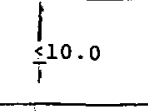 & $\leq 10.0$ & $\leq 10.0$ &.$\leq 10.0$ & $\leq 10.0$ & $\leq 5.0$ \\
\hline VOLATILITY & NA & NA & $\begin{array}{l}.1,000^{\circ} \mathrm{K} \\
\text { Ru \& \& cs } \\
\end{array}$ & $\begin{array}{l}1,200^{\circ} \mathrm{K} \\
\text { al1 } \\
R u \text { \& } \mathrm{Cs}\end{array}$ & $\begin{array}{l}1,200^{\circ} \mathrm{K} \\
\text { and } 8 \mathrm{Cs} \\
\mathrm{Ru}\end{array}$ & 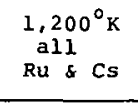 & $\begin{array}{l}\begin{array}{r}1,200^{\circ} \mathrm{K} \\
\text { all } \\
\mathrm{Ru} \& \mathrm{Cs}\end{array} \\
\end{array}$ & $\begin{array}{l}1,570^{\circ} \mathrm{K} \\
\text { some } \\
\text { Ru \& C Cs }\end{array}$ & $\begin{array}{l}1,670^{\circ} \mathrm{K} \\
\text { much } \\
\mathrm{Ru} \& \mathrm{cs}\end{array}$ & $\begin{array}{l}1,670^{\circ} \mathrm{K} \\
\text { al1 } \\
\text { Ru } \& \mathrm{cs}\end{array}$ & $\begin{array}{l}<1,500^{\circ} \mathrm{K} \\
\text { all } \\
\mathrm{Ru} \& \mathrm{Cs}\end{array}$ & $\begin{array}{l}<1,500^{\circ} \mathrm{K} \\
\text { all1 } \\
\mathrm{Ru} \& \mathrm{Cs}\end{array}$ & 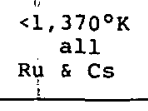 & 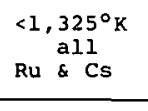 & $\begin{array}{l}<1 ; 620^{\circ} \mathrm{K} \\
\mathrm{a} 111 \\
\mathrm{Ru} \& \mathrm{Cs}\end{array}$ & $\begin{array}{l}<1,525^{\circ} \mathrm{K} \\
\mathrm{Ra1}=\mathrm{al} \\
\mathrm{Ru} \& \mathrm{Cs}\end{array}$ & $\begin{array}{l}<1,670^{\circ} \mathrm{K} \\
\text { all } \\
\text { a cs }\end{array}$ & NA \\
\hline $\begin{array}{l}\text { SPECIFIC } \\
\text { VOLUME }\end{array}$ & $\frac{\mathrm{m}^{3}}{\mathrm{MgU}}$ & - & $\begin{array}{l}n .05 \\
\text { it } \\
1.0 \\
\end{array}$ & $\begin{array}{l}.03 \\
\text { to } \\
.06 \\
\end{array}$ & $\begin{array}{l}0,044 \\
\text { to } \\
0.058\end{array}$ & 0.045 & $\begin{array}{l}0.032 \\
\text { to } \\
0.040 \\
\end{array}$ & $0.0 / 0$ & v.uiv & $0.130^{\circ}$ & $\begin{array}{l}0.036 \\
0.45 \\
0.078 \\
\end{array}$ & $\begin{array}{l}0.04 \\
0.04 \\
0.1\end{array}$ & $\begin{array}{l}0.03 \\
1.03 \\
0.055\end{array}$ & 0.077 & $0 \cap 8$ & $\cap \cap 8$ & กं. .550 & $\begin{array}{l}4 \\
\text { th } \\
40\end{array}$ \\
\hline $\begin{array}{l}\text { WEIGIT FERCENT } \\
\text { WASTRP PROMICT } \\
\text { UXIUES }\end{array}$ & $\begin{array}{l}\text { MAXIMUM } \\
\text { TYFICAL }\end{array}$ & $\begin{array}{l}58 \\
48 \\
\end{array}$ & $\begin{array}{l}\leq 808 \\
\leq 808\end{array}$ & $\begin{array}{l}\leq 1008 \\
\leq 1008 \\
\end{array}$ & $\begin{array}{l}\leq 908 \\
\leq 9018 \\
\leq 9\end{array}$ & $\begin{array}{l}\leq 1008 \\
\leq 100 i 8\end{array}$ & $\begin{array}{l}\leq 1008 \\
\leq 1008 \\
\leq 100\end{array}$ & $\begin{array}{l}\leq 758 \\
458 \\
\end{array}$ & $\begin{array}{c}\leq 758 \\
458 \\
\end{array}$ & $\begin{array}{c}\leq 808 \\
458 \\
\end{array}$ & $\begin{array}{l}\leq 258 \\
208 \\
\end{array}$ & $\begin{array}{r}\leq 508 \\
20-358 \\
\end{array}$ & $\begin{array}{l}508 \\
458 \\
\end{array}$ & $\begin{array}{l}308 \\
258 \\
\end{array}$ & $\begin{array}{l}508 \\
208 \\
\end{array}$ & $\begin{array}{r}\leq 658 \\
338 \\
\end{array}$ & $\begin{array}{r}\leq 808 \\
258 \\
\end{array}$ & $\begin{array}{r}108 \\
58 \\
\end{array}$ \\
\hline $\begin{array}{l}\text { SPECIFIC } \\
\text { AREA }\end{array}$ & $\frac{\mathrm{m}^{2}}{\mathrm{~K} y}$ & - & $\begin{array}{l}100 \\
\text { too } \\
5,000\end{array}$ & $\begin{array}{l}10,000 \\
\text { to } \\
20,000\end{array}$ & $\begin{array}{l}100 \\
\text { to } \\
5,000\end{array}$ & $\begin{array}{l}100 \\
\substack{100 \\
\text { s, } \\
5,000} \\
\end{array}$ & $\begin{array}{l}100 \\
\substack{100 \\
5,000} \\
5,00\end{array}$ & $\begin{array}{l}10,000 \\
\text { to } \\
20,000\end{array}$ & $\begin{array}{l}0.005 \\
0.05 \\
0.05\end{array}$ & $\begin{array}{l}100 \\
\text { to } \\
\text { sonon }\end{array}$ & $\begin{array}{l}0.005 \\
\text { to } \\
0.05\end{array}$ & $\begin{array}{l}0.005 \\
\text { to. } \\
0.05\end{array}$ & $\begin{array}{l}\vdots 0.1 \\
t+0 \\
t .0\end{array}$ & $\begin{array}{l}0.005 \\
\text { to. } \\
0.05\end{array}$ & $\begin{array}{l}0.005 \\
\text { to } \\
0.05\end{array}$ & $\begin{array}{l}0.005 \\
\text { to } \\
0.05\end{array}$ & $\begin{array}{l}0.005 \\
\begin{array}{l}0.005 \\
0.05\end{array}\end{array}$ & NA \\
\hline FORM & NA & 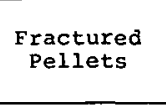 & $\begin{array}{l}\text { Mono- } \\
\text { lithic }\end{array}$ & Powdex & $\begin{array}{c}\text { Powder } \\
\text { or } \\
\text { scale }\end{array}$ & Powder & Granulax & Powder & Monolithic & Beads & $\begin{array}{l}\text { Practured } \\
\text { Monolith }\end{array}$ & $\begin{array}{l}\text { Fractured } \\
\text { Monolith }\end{array}$ & Pél1ets & $\begin{array}{l}\text { Mono- } \\
\text { lithic }\end{array}$ & $\begin{array}{l}\text { Mono- } \\
\text { 1ithic }\end{array}$ & $\begin{array}{c}\text { Mono- } \\
\text { 1ithic }\end{array}$ & $\begin{array}{c}\text { Mono- } \\
\text { 1ithic }\end{array}$ & 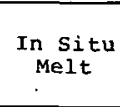 \\
\hline $\begin{array}{l}\text { STRUCTURAL } \\
\text { QUALLITY }\end{array}$ & NA & 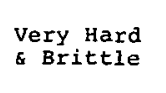 & Crumbly & $\begin{array}{l}\text { Soft \& } \\
\text { crumb } 2 y\end{array}$ & 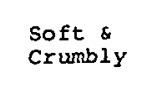 & 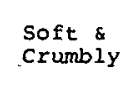 & $\begin{array}{l}\text { Softe } \\
\text { crumbiy }\end{array}$ & $\begin{array}{l}\operatorname{soft}_{\text {crumbly }} \\
\text { crum }\end{array}$ & $\underset{\substack{\text { Very Hard } \\
\text { \& Britttle }}}{2}$ & наrd & $\begin{array}{l}\text { Very Hard } \\
\text { Sirittle }\end{array}$ & $\begin{array}{l}\text { very Hard } \\
\text { \& Brittie }\end{array}$ & very ната & $\begin{array}{l}\text { Rard } \\
\text { Tough }\end{array}$ & 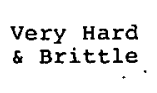 & $\begin{array}{l}\text { Hard } \delta \\
\text { Ductile }\end{array}$ & $\begin{array}{c}\text { Hard } \delta \\
\text { Brittle }\end{array}$ & нахd \\
\hline POROSITY & 8 & $\begin{array}{c}2 \\
\text { to } \\
10 \\
\end{array}$ & 0 & $\begin{array}{l}30 \\
\text { to } \\
75\end{array}$ & $\begin{array}{l}40 \\
\text { to } \\
85\end{array}$ & $\begin{array}{l}70 \\
\text { to } \\
80 \\
\end{array}$ & $\begin{array}{l}45 \\
\text { to } \\
80\end{array}$ & 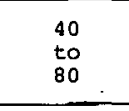 & $\begin{array}{l}2 \\
\text { to } \\
20\end{array}$ & $\leq 20.0$ & $\leq 5.0$ & $\leq 1.0$ & $\begin{array}{r}8 \\
\text { to } \\
125 \\
\end{array}$ & $\leq 10.0$ & $<5.0^{\circ}$ & $\leq 10.0$ & $\leq 3.0$ & $\leq 5.0$ \\
\hline DENSITY & $\frac{\mathrm{kg}}{\mathrm{m}^{3}}$ & $\begin{array}{l}10,000 \\
t=0 \\
10,500 * *\end{array}$ & 1,700 & $\begin{array}{l}1,000 \\
\text { too } \\
2,400\end{array}$ & $\begin{array}{l}1,100 \\
1,40 \\
1,400\end{array}$ & 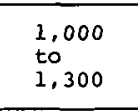 & $\begin{array}{l}2,000 \\
\text { to } \\
2,400\end{array}$ & 4,000 & $\begin{array}{l}3,500 \\
\text { to } \\
4,000\end{array}$ & 1,700 & $\begin{array}{l}2,700 \\
\text { to } \\
3,000\end{array}$ & $\begin{array}{l}3,000 \\
\text { to } \\
3,600 \\
\end{array}$ & $\begin{array}{l}2,400 \\
l, t, 00 \\
3,300\end{array}$ & $2,850^{\circ}$ & 3,000 & $\begin{array}{l}2,400 \\
\text { to } \\
5,500 \\
\end{array}$ & $£ 4,500$ & 2,700 \\
\hline 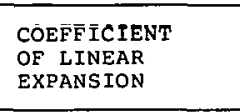 & $\times 10^{-6},{ }^{\circ} \mathrm{K}$ & ข10** & 0 & ๑8.3 & 28.3 & 28.3 & 28.3 & 28.3 & $\begin{array}{l}8 \\
\text { to } \\
10\end{array}$ & $\sim 4.5$ & $\begin{array}{l}8 \\
\text { to } \\
10\end{array}$ & $\begin{array}{c}8 \\
\text { to } \\
10\end{array}$ & 8.0 & $\begin{array}{l}9.0 \\
\text { to. } \\
1.3 \\
\end{array}$ & 210 & 229 & 104.2 & $\begin{array}{l}9.0 \\
\begin{array}{l}l u \\
4.0\end{array} \\
4.0\end{array}$ \\
\hline $\begin{array}{l}\text { THERMAL } \\
\text { CONDUCTIVITY }\end{array}$ & $\frac{W}{m^{0} \bar{K}}$ & $\begin{array}{c}2 * * \\
\text { too } \\
6\end{array}$ & $\begin{array}{l}0.1 \\
\text { to. } \\
0.5\end{array}$ & 0.2 & $\begin{array}{l}0.35 \\
\text { to } \\
1.0\end{array}$ & 0.2 & $\begin{array}{l}0.2 \\
\text { to } \\
0.3\end{array}$ & 0.6 & $\begin{array}{l}0.8 \\
\text { to } \\
2\end{array}$ & 17 & $\begin{array}{c}0.8 \\
\text { to } \\
1.3 \\
\end{array}$ & $\begin{array}{r}0.9 \\
\text { to } \\
1.3\end{array}$ & $\{0.7$ & 2.2 & 1.2 & $\begin{array}{c}5 \\
\text { to } \\
35\end{array}$ & 1.2 & $\begin{array}{l}1.0 \\
\text { to } \\
1.5\end{array}$ \\
\hline $\begin{array}{l}\text { HEAT } \\
\text { CAPACITY }\end{array}$ & $\frac{\mathrm{J}}{\mathrm{Kg}^{\circ} \mathrm{K}}$ & $\begin{array}{l}238 * * \\
\text { to } \\
330\end{array}$ & $\begin{array}{l}500 \\
\text { to } \\
800\end{array}$ & 650 & 650 & 650 & 650 & 670 & $\begin{array}{l}1,100 \\
1,00 \\
1,200 \\
\end{array}$ & 680 & $\begin{array}{l}1,100 \\
, t 00 \\
1,200 \\
\end{array}$ & 750 & $\begin{array}{l}1,100 \\
1,00 \\
i, 200 \\
t, 200\end{array}$ & $\begin{array}{l}1,100 \\
\text { to } \\
1,200\end{array}$ & $\begin{array}{l}1,100 \\
\text { to } \\
1,200\end{array}$ & 350 & 550 & $\begin{array}{l}1,000 \\
\text { to } \\
1,600\end{array}$ \\
\hline $\begin{array}{l}\text { LIRUIDUS } \\
\text { TEMPERATURE }\end{array}$ & ${ }^{\circ} \mathrm{K}$ & $-3,138 * *$ & 520 & 1,670 & $1,670^{\circ}$ & 1,670 & 1,670 & $\begin{array}{r}1,670 \\
\text { to } \\
1,870 \\
\end{array}$ & $\begin{array}{l}1,670 \\
1,60 \\
1,870\end{array}$ & 2,570 & $\begin{array}{l}820 \\
\text { to } \\
1,020\end{array}$ & $\begin{array}{l}800 \\
\text { to } \\
1,500\end{array}$ & {$\left[\begin{array}{l}970 \\
1,0 \\
1,500\end{array}\right.$} & 1,070 & 850 & 600 & 2,290 & 1,320 \\
\hline $\begin{array}{l}\text { TRRASITI ION } \\
\text { TEMEERAYUUEE }\end{array}$ & ${ }^{\circ}{ }_{K}$ & NA & ผล & $\mathrm{NA}$ & Nล & NA & NA & . $\mathrm{NA}$ & $\mathrm{NA} \cdot$ & NA & 770 & $\begin{array}{l}870 \\
\text { to } \\
970\end{array}$ & NA & NA & 900 & $\star \star \star *$ & NA & $\mathrm{NA}$ \\
\hline
\end{tabular}

KEY TO SYMBOLS

- Not Available.

* = Mostly stress cor

** = Mostly stress corrosion cracking which is localized, vased on

$* * *=$ Alloy has a transition temperaturc. 
particular chemical composition that, by variations in processing, can be either rapidly dried from a liquid to give a non-crystalline powder (= calcine), or melted into a glass, or slowly cooled to give the stable crystalline form for that composition. The free energy states of the three solids can be represented schematically as in Figure 1 (A).

A fundamental law of chemical reactions states that a reaction proceeds in the direction of lower free energy (G). Figure 1.(A) is a schematic presentation of the fact that, for a given chemical composition, the calcine and glass forms are unstable with respect to the stable rrystalline phase form at the temperaturo of intcrcot. The calcine and glass have excess free energy compared to the crystalline form due to their more disordered structural states. This is the reason that devitrification (crystallization) studies are such an important part of glass waste form evaluation. It is not enough to evaluate the properties of the metastable glass alone when the possibility exists that the glass will devitrify at some time during its functional lifetime.

Our studies are not aimed at phase changes in a solid, from less to more stable forms, but in reactivity in a geologic envisumment. The alsordered structural state which results in excess free energy for calcine and glass can also enhance reactivity. Thermodynamics predict when a reaction can occur, but does not predict that it will occur. There is often a substantial activation energy blocking a thermodynamically favorable reaction. Consider again, the three solld forms of the same composition. In Figure 1 (B), it is seen that the crystal can undergo some reaction, for example dissolution 


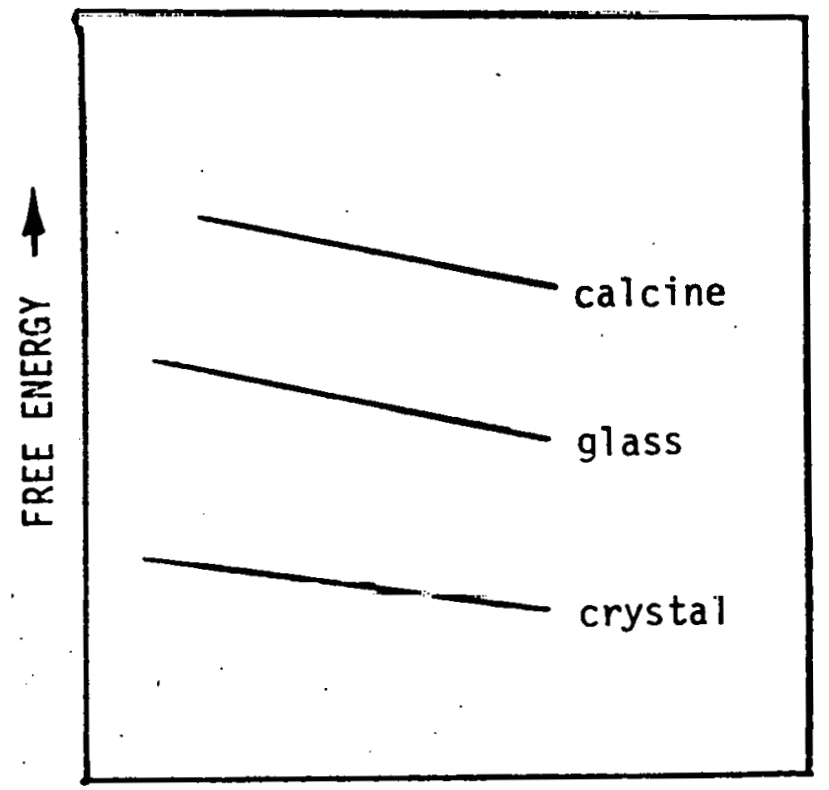

temperature

(A)

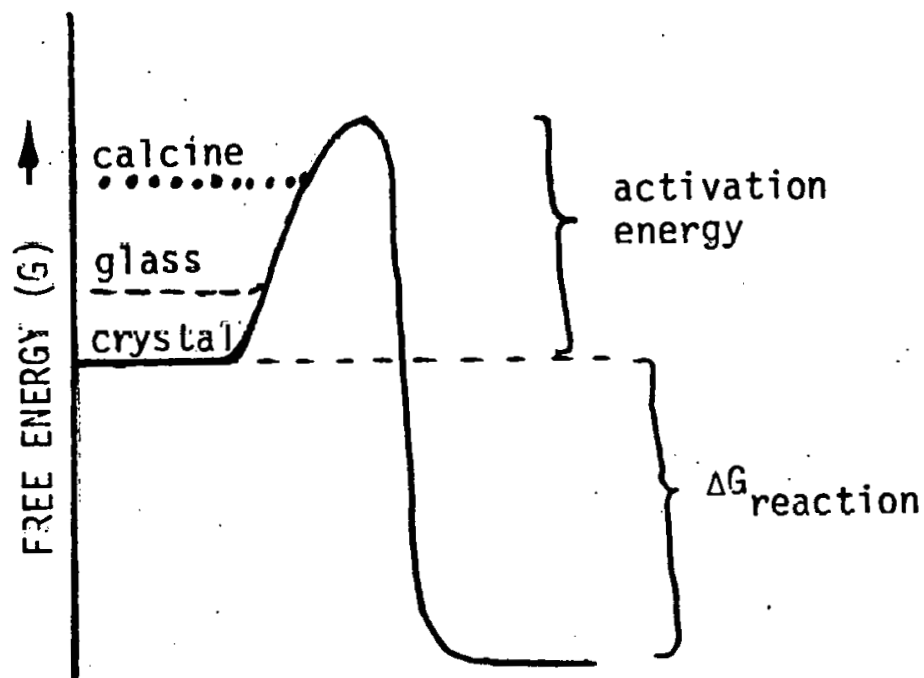

(B)

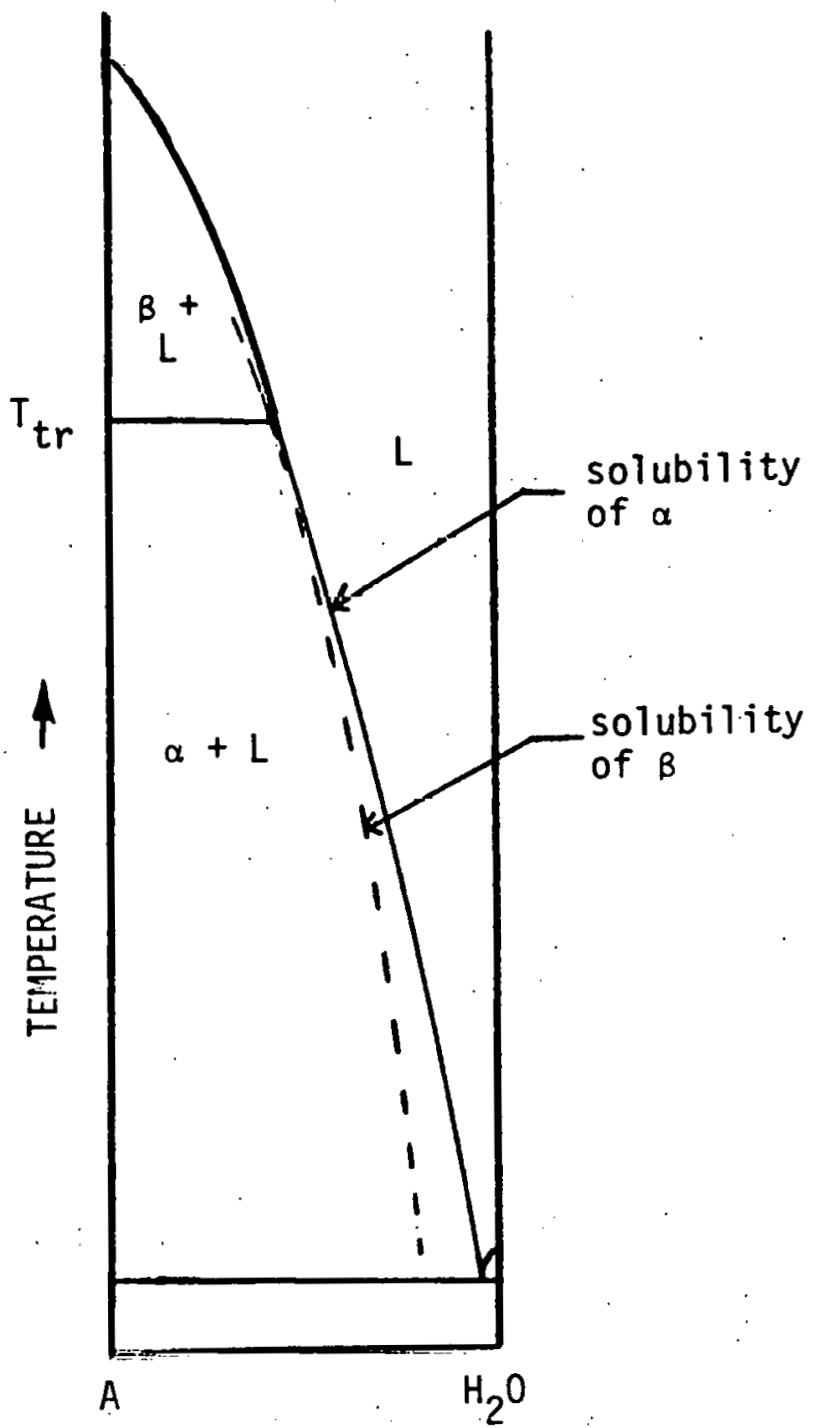

(C)

\section{FIGURE 1}

(A) SCHEMATIC REPRESENTATION FOR THE RELATIVE FREE ENERGIES OF THREE SOLID FORMS OF' THE SAME CHEMICAL COMPOSITION.

(B) SCHEMATIC REPRESENTATION OF THE ACTIVATION ENERGY BARRIER FOR A THERMODYNAMICALLY FAVORABLE REACTION FOR EACH OF THE THREE SOLID FORMS.

(C) PHASE DIAGRAM FOR THE SYSTEM A-H 2 O WHERE A HAS TWO POLYMORPHIC FORMS $\alpha$ AND $\beta$. BELOW $T_{t r}, \beta$ IS MORE SOLUBLE THAN $\alpha$. 
in water, but a substantial activation energy first needs to be overcome. That activation energy is less for the calcine and glass because of their excess free energy. A clear illustration of this is provided by the work of Hawkins and Roy ${ }^{4}$ on the hydrothermal alterations of basalts. They compared the reactivity of the crystalline basalts with chemically identical glasses and desiccated gels ( $\approx$ calcine) and found that "for a given crystalline rock, glass and gel, all of the same composition (with other conditions constant...), the glass and gel were readily altered while the crystalline rock was altered only slightly, if at all."

Indeed, desiccated gels and glasses as starting materials have been used for the last three decades of hydrothermal mineralogy and petrology studies because they are so reactive and, therefore, provide a more rapid approach to equilibrium. 5

Another example of why the thermodynamic state of a solid is relevant to waste reactions is illustrated in Figure 1 (C). Phase A has two crystalline forms $\alpha$ and $\beta$. At all temperatures below $T_{t r}$, the phase $\beta$ is metastable and has excess free energy. It is more soluble in water.

Based on the above discussion, it is to be expected that calcine and glass waste forms will be more reactive in the geologic environment than the largely crystalline forms spent unreprocessed fuel and supercalcine.

Because of the importance of this concept to waste/basalt interactions, the thermodynamic state of the phases (crystalline or noncrystalline) is a major waste form 
characteristic and will, therefore, be discussed for each of the waste forms.

\section{CHEMICAL COMPOSITION}

Chemical composition is another important characteristic, since chemical potential differences will provide the major thermodynamic driving force for interactions in the geologic environment and the kinds of ions available determine the types of phases formed.

\section{HISTORY OF WASTE FORM}

The third important class of characteristics of radioactive waste affecting waste/basalt interactions includes the fuel burn-up, the age (i.e., time out of reactor) of the waste, and, in some cases, waste loading. These determine how much heat is produced by a given volume of radioactive waste. How much heat will be available in the interaction zone of the immediate repository is largely an engineering parameter. Results from our waste/basalt interaction studies may be an important factor in determining how much of a temperature rise should be allowed in the immediate repository and, thus, in the placement of waste canisters.

\section{LEACHABILITY}

Although considerable data are available under the heading of leachability, we will not be giving much attention to it in this section. Simply stated, most of the leachability measurements have been taken by the Paige $\left(25^{\circ} \mathrm{C}\right)$, Soxhlet $\left(95^{\circ} \mathrm{C}\right)$, or the International Atomic Energy Agency $\left(25^{\circ} \mathrm{C}\right)$ distililed water methods 6 
and are not representative of leaching behavior under the hydrothermal conditions which are of concern in the immediate repository during the thermal period.

\section{MISCELLANEOUS FACTORS}

There are several. other types of data having relevance to waste/basalt interactions. The surface area per unit mass of the waste form will certainly affect the interaction kinetics. Radiation effects, with their accompanying stored energy, will provide some activation to the interactions. However, the magnitude of this contribution should be on the order of a few tens of calories or less, whereas the thermochemical driving force for interactions will be on the order of kilocalories. It should also be pointed out that the radiation damage will be occurring during the thermal period so that much of it may be annealed out before it can contribute to waste/basalt interactions. Finally, it should be noted that solutions impinging on the waste form may be somewhat more reactive than natural hydrothermal solutions due to radiolysis of the water and other constituents.

\section{DISCUSSION}

SPENT UNREPROCESSED FUEL

Eighty percent of our experimental and theoretical efforts are presently being directed toward studying the chemical interaction of spent unreprocessed fuel and basalt. These studies should be instrumental in evaluating the geochemical feasibility of storing spent unreprocessed fuel in a basalt environment. 
The physical and chemical data needed to evaluate the feasibility of storing unreprocessed fuel in a basalt repository are limited. However, the thermodynamic state of spent unreprocessed fuel should be governed largely by its phase composition. The major phase is a crystalline fluorite structure $\left(\mathrm{UO}_{2}\right)$ with fluorite-related structure fission product oxides $\left(\mathrm{RE}_{2}^{\star} \mathrm{O}_{3}, \mathrm{CeO}_{2}\right.$, and some $\left.\mathrm{ZrO}_{2}\right)$ in solid solution. After a survey of papers on irradiated fuel behavior, it became clear that very little else is actually known about spent unreprocessed fuel crystalline phase behavior. It is widely believed that sro and BaO react with $\mathrm{ZrO}_{2}$ to form the perovskite structure $\left[(\mathrm{Ba}, \mathrm{Sr}) \mathrm{ZrO}_{3}\right]$. There also appear to be distinct Cs-Te-rich zones. Cesium is thought to be present as a cesium molybdate and/or a cesium uranate, both of which are quite soluble in water. Spent unreprocessed fuel would have a stability level in the neighborhood of the crystalline phase depicted in Figure 1 (A). Preliminary experiments seem to bear this out, since spent unreprocessed fuel appears fairly unreactive relative to glass and calcine.

We anticipate that the bulk of the $\mathrm{UO}_{2}$-rich spent. unreprocessed fuel waste form would remain relatively unreactive under hydrothermal repository ambients, as long as the Eh-pH conditions keep the uranium in the tetravalent state. If the conditions become

* RE is a shorthand notation for a group of rare earth elements. As a group, they exhibit nearly identical chemical properties: This notation allows us to write a general formula which represents the group as a whole. 
too oxidizing, then the uranium could be mobilized and the $\mathrm{UO}_{2}$ would no longer be able to act as a protective matrix for the more soluble fission products and actinides.

There are data showing ${ }^{l}$ that the composition of a mixed oxide spent unreprocessed fuel having had a burn-up of 25,000 megawatt days per metric ton of heavy fuel is approximately 97 percent $\mathrm{UO}_{2}$ with a balance comprised of fission products and transuranic elements. In order to provide an approximate simulation of the chemistry of spent unreprocessed fuel in early preliminary experiments, we used a mixture of 95 weight percent $\mathrm{UO}_{2}$ plus 5 weight percent $\mathrm{PW}-4 \mathrm{~b}$. * These were sintered in an attempt to simulate actual spent unreprocessed fuel conditions where the fission products are more typically part of a more complex compound or part of the $\mathrm{UO}_{2}$ solid solution. No effort has been made as yet to include volatiles, especially iodine. Some of the runs in the Euture will also contain zircaloy and other alloys in addition to spent unreprocessed fuel and basalt.

There are leachability data on actual spent unreprocessed fuel, 7 at $25^{\circ} \mathrm{C}$. Hanford ground water, as well as deionized water, were the leachants. The relative leachability of the elements decreased in the order: $\mathrm{Cs}>\mathrm{Sb}>\mathrm{Sr}+\mathrm{Y}>\mathrm{Pu}$ $>\mathrm{Cm}$ with ${ }^{137} \mathrm{Cs}$ leach rates of $\sim 5 \times 10^{-6}$ grams per centimeter per day after 21 weeks

\section{CALCINE}

Calcine is the general name for unconsolidated powder or granules made by the single-step process of evaporation (and partial decomposilioil) of liquid high-level waste.

\footnotetext{
* $\mathrm{PW}-4 \mathrm{~b}$ is a simulated low sodium Purex process waste.
} 
Calcine may have once been considered as a final waste form; but, today, calcine is typically referred to and considered as an intermediate step before consolidation to, or incorporation into, some other form.

The composition of calcines is very much a function of the reprocessing flow sheet. An ideal or "clean" calcine would have mainly fission product oxides. A flow sheet which calls for mixing the intermediate with the high-level waste stream will give.a calcine with a substantial sodium and phosphate content. The efficiency of separations will determine how much uranium and plutonium remain in the waste stream. The calcine used in our studies is the "dirty"* high-uranium U. S. Department of Energy formulation PW-7a. It was formulated at one time to be typical of the high-level waste from the Nuclear Fuel Services Reprocessing Plant. Table II lists the compositions of two typical calcines: PW-4b ("Clean"); and, PW-7a ("Dirty"): PW-7a is an especially representative simulated calcine, in that it contains all of the correct chemical elements (except the radioactives: $\mathrm{TC} ; \mathrm{Pm}$; $\mathrm{Np} ; \mathrm{Pu} ; \mathrm{Am} ; \mathrm{Cm}$ ) including the expensive elements $\mathrm{Pd}, \mathrm{Rh}$, and $\mathrm{Ru}$. It was supplied to us in 1974 as $\mathrm{PW}-4 \mathrm{~b}$. We have converted it into a PW-7a composition by adding the appropriate amounts of extra $\mathrm{Na},\left(\mathrm{PO}_{4}\right)$, $\mathrm{Fe}$, and $\mathrm{U}$.

The phase compositions of the calcine are important, since the crucial question of the solubility or leachability of hazardous radionuclides is principally

* "Dirty" is equivalent to high sodium; "clean" is equivalent to low sodium. 


\section{TABLE II}

COMPOSITIONS OF POTENTIAL COMMERCIAL REPROCESSING HIGH-LEVEL WASTE CALCINES

(Weight. Percent)

\begin{tabular}{|c|c|c|}
\hline Oxide & PW-4b ("Clean")* & PW-7a ("Dirty")* \\
\hline $\mathrm{Na}_{2} \mathrm{O}$ & - & 9.1 \\
\hline $\mathrm{P}_{2} \mathrm{O}_{5}$ & 1.6 & 8.3 \\
\hline $\mathrm{RE}_{2} \mathrm{O}_{3}$ ** & 31.8 & 30.5 \\
\hline $\mathrm{ZrO}_{2}$ & 12.1 & 6.5 \\
\hline $\mathrm{MoO}_{3}$ & 12.6 & 6.8 \\
\hline $\mathrm{To}_{2} \mathrm{O}_{\overline{7}}$ & 3.2 & 1.7 \\
\hline $\mathrm{RuO}_{2}$ & 7.3 & 3.9 \\
\hline PdO & 3.6 & 2.0 \\
\hline $\mathrm{Cs}_{2} \mathrm{O}$ & 7.0 & 3.8 \\
\hline $\mathrm{Rb}_{2} \mathrm{O}$ & 0.9 & 0.5 \\
\hline sro & 2.6 & 1.4 \\
\hline $\mathrm{BaO}$ & 3.8 & 2.1 \\
\hline $\mathrm{u}_{3} \mathrm{O}_{8}$ & 2.9 & 15.4 \\
\hline $\mathrm{Rb}_{2} \mathrm{O}$ & 0.9 & 0.5 \\
\hline $\mathrm{TeO}_{2}$ & 1.8 & 1.0 \\
\hline $\mathrm{Fe}_{2} \mathrm{O}_{3}$ & 3.7 & 4.0 \\
\hline $\mathrm{Cr}_{2} \mathrm{O}_{3}$ & 0.8 & 0.5 \\
\hline NiO & 0.3 & 0.2 \\
\hline $\mathrm{PuO}_{2}$ & 0.2 & 0.1 \\
\hline Others & 2.7 & 1.6 \\
\hline
\end{tabular}

*Calculated from data in Table 2 of Mendel, et al. ${ }^{\star}{ }_{\mathrm{RE}}=\mathrm{La}, \mathrm{Ce}, \mathrm{Pr}, \mathrm{Nd}, \mathrm{Pm}, \mathrm{Sm}, \mathrm{Eu}, \mathrm{Gd}, \mathrm{Tb}, \mathrm{Dy}, \mathrm{Y}$. 
determined by the phase into which they are incorporated. Thus, $\mathrm{Sr}^{++}$in $\mathrm{SrCl}_{2}$ is over a million times more leachable than $\mathrm{Sr}^{++}$in $(\mathrm{Sr}, \mathrm{Ca}) \mathrm{Al}_{2} \mathrm{Si}_{2} \mathrm{O}_{8}$. $\mathrm{X}$-ray studies of some calcines indicate that the typical calcine is a mixture of two or three "phases" each poorly crystallized or nearly non-crystalline. As McCarthy and Davidson ${ }^{8}$ have shown, crystalline phases can be formed in calcines heated briefly to temperatures above. $\sim 900^{\circ} \mathrm{C}$. However, during these firings, much or all of the $\mathrm{Cs}, \mathrm{Rb}, \mathrm{Na}, \mathrm{Mo}, \mathrm{Ru}$, and $\mathrm{Te}$ in the calcines are volatilized. This poor thermal stability makes it unlikely that ordinary calcines would be treated at temperatures high enough to crystallize them significantly, even though this would increase thermodynamic stability.

We have heat-treated $\mathrm{PW}-7 \mathrm{a}$ at $800^{\circ} \mathrm{C}$ for 2 hours in order to simulate the "stabilization" (i.e., elimination of most of the volatile $\mathrm{NO}_{x}$ and $\mathrm{H}_{2} \mathrm{O}$ ) step which would be used before sealing calcine canisters. ${ }^{1}$ Even after the heating, $x$-ray diffraction shows that the calcine remains largely amorphous.

"Leachability" of calcine, even in room temperature water, would be expected to be high because of its high surface area per unit mass and the likely presence of water soluble "phases;" e.g., (Na,Cs) $2^{\mathrm{MoO}_{4}}$. Mendel and McElroy ${ }^{9}$ report that 20 to 25 percent of the constituents of a typical calcine dissolve readily on contact with water. This means that a substantial fraction of a calcine will be immediately available in solution during hydrothermal waste/basalt interaction experiments. 
"Waste loading" in calcine is essentially 100 percent. However, in a canister, the amount of the low-density. calcine ( $z$ l gram per cubic centimeter) would be equivalent to another product of higher density ( 3.0 grams per cubic centimeter) with 33 weight percent loading.

\section{$\underline{\text { GLASS }}$}

Development of vitrification processes for solidification of high-level waste began more than two decades ago in the United States and abroad. As far back as ten years ago, a pilot-scale hot demonstration of phosphate and borosilicate glass processing was under way at the Hanford site (the Waste soliditication Engineering Prototypes Program). In the future, Battelle-Northwest will be demonstrating in-can solidification by vitrification of actual high-level waste made by onsite reprocessing of spent fuel. Clearly, glass was the waste form closest to utilization for the near term and, for this reason, it was previously given the greatest consideration in our waste/basalt interactions program.

It is widely appreciated that glass is in an excess free energy state compared to the assemblage of equilibrium crystalline phases of the same bulk composition. It is for this reason that high-level waste glasses are subject to "devitrification" (partial crystallization) on slow cooling and when held in the temperature range of 500 to $800^{\circ} \mathrm{C}$. The Battelle-Northwest Glass 72-68 has been shown to devitrify into $(\mathrm{Ca}, \mathrm{Sr}, \mathrm{Ba}) \mathrm{MoO}_{4}, \mathrm{Zn}_{2} \mathrm{SiO}_{4}$, $(\mathrm{Zn}, \mathrm{Ni})(\mathrm{Fe}, \mathrm{Cr})_{2} \mathrm{O}_{4}$, and $\mathrm{Ca}_{2} \mathrm{RE}_{8}^{\star}\left(\mathrm{SiO}_{4}\right)_{6} \mathrm{O}_{2}$ after these

\footnotetext{
* See Table III.
} 


\section{TABLE III}

COMPOSITION OF BATTELLE-NORTHWEST GLASS 76-68*

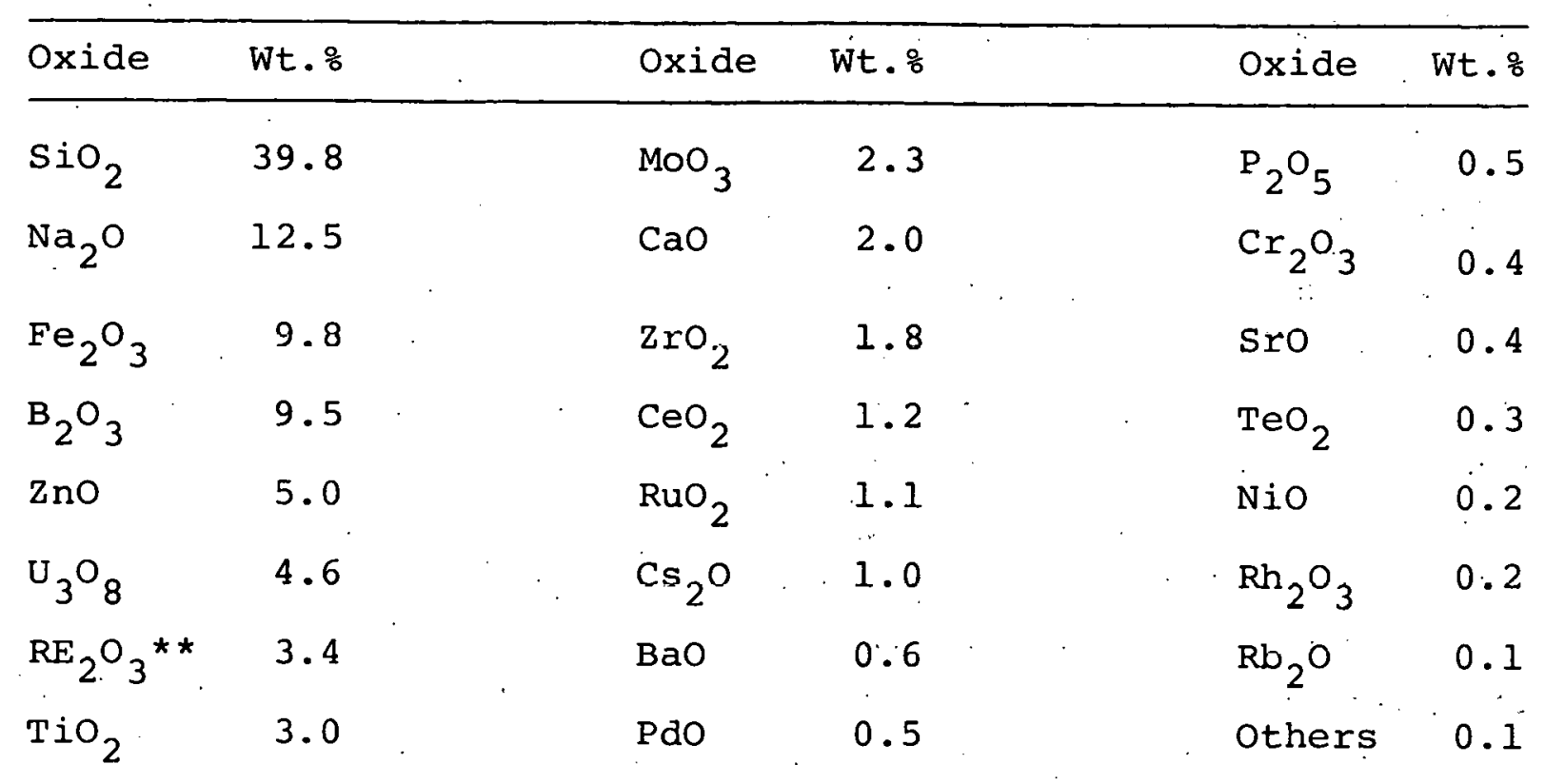

*Moditied from a table provided by D. Bradley, Battelle-Northwest. $\star * \mathrm{RE}=\mathrm{La}, \mathrm{Pr}, \mathrm{Nd}, \mathrm{Sm}, \mathrm{Eu}, \mathrm{Gd}, \mathrm{Y}$. 
thermal treatments. In addition, crystalline $\mathrm{RuO}_{2}$, (Ce...) $\mathrm{O}_{2}$ and $\mathrm{Pd}$ were also present in the freshly formed glass as undissolved components. 6

Investigators have observed hitherto unreported glassin-glass phase separation by transmission electron microscopy. Thus, high-level waste "glass" falls between glass and crystal in Figure 1 (A) and (B). Thus, we would expect glass to be intermediate in reactivity between calcine and the more completely crystallized supercalcine and spent unreprocessed fuel during our waste/basalt interactions studies.

The specitic glass we have chosen in our interactions studies is exactly the same specimen being used in the source term characterization task of the office of Waste Isolation/Battelle-Northwest/Waste Isolation Safety Assessment Program. Its code is 76-68 and the specimen was provided by J. E. Mendel of Battelle-Northwest. With regard to the above discussion on devitrification, it should be noted that 76-68 shows significantly less devitrification than 72-68. I0 Only $\mathrm{Ru}, \mathrm{RuO}_{2}$, two spinel phases, and $(\mathrm{U}, \mathrm{Ce} . ..) \mathrm{O}_{2 \pm \mathrm{x}}$ have been noted to date in heat-treated $76-\overline{6} 8$.

The composition of Glass $76-68$ is given in Table III. The waste composition $(\mathrm{PW}-8 \mathrm{a})$ used to prepare Glass 76-68 was calculated to be typical of one of the highlevel wastes to have been generated by the Nuclear Fuel Services Reprocessing Plant. $\mathrm{PW}-8 \mathrm{a}$ is similar in composition to $\mathrm{PW}-7 \mathrm{a}$ (Table II), except that it has approximately 2 times the sodium and approximately 9 times the iron. 
PW-8a was combined with a glass-making frit, which can be described as a soda-lime-zinc-titanium borosilicate. It should be noted that this simulated high-level waste glass composition $(76-68)$ is as representative as it can be without including the radioactive elements. In Table III, the oxides have been listed in order of decreasing concentration. The molybdenum oxide is approximately 20 percent greater than it would be in actual high-level waste, because Mo has been used as a "stand-in" for TC.

\section{SUPERCALCINE}

McCarthy, et al., 11-13 have described the first successful supercalcine formulations. The basic premise of this tailor-made ceramic is that modifications can be made to high-level liquid waste compositions through the addition of selected liquid additives so that, when the liquid is calcined and given additional heat treatment, an assemblage of refractory and leach-resistant phases is crystallized. The name "supercalcine" was coined to indicate a common processing operation with "calcine." An important component of this research has been the collaboration with Battelle-Northwest where engineering-scale "cold" demonstrations and product characterization have been performed.

To date, McCarthy and his co-workers have succeeded in the development of effective formulations for converting both "clean" and "dirty" high-level liquid waste (see Table II) into compatible assemblages of refractory and leach-resistant phases. Table IV lists these phases and structure types. The mix of phases differs with the waste composition. Additions of nitrates of $\mathrm{Ca}, \mathrm{Sr}$, and Al, plus soluble forms of silica, are made to the 


\section{TABLE IV}

\section{FIXATION PHASES FOR HIGH-LEVEL WASTE \\ CONSTITUENTS IN SUPERCALCINE}

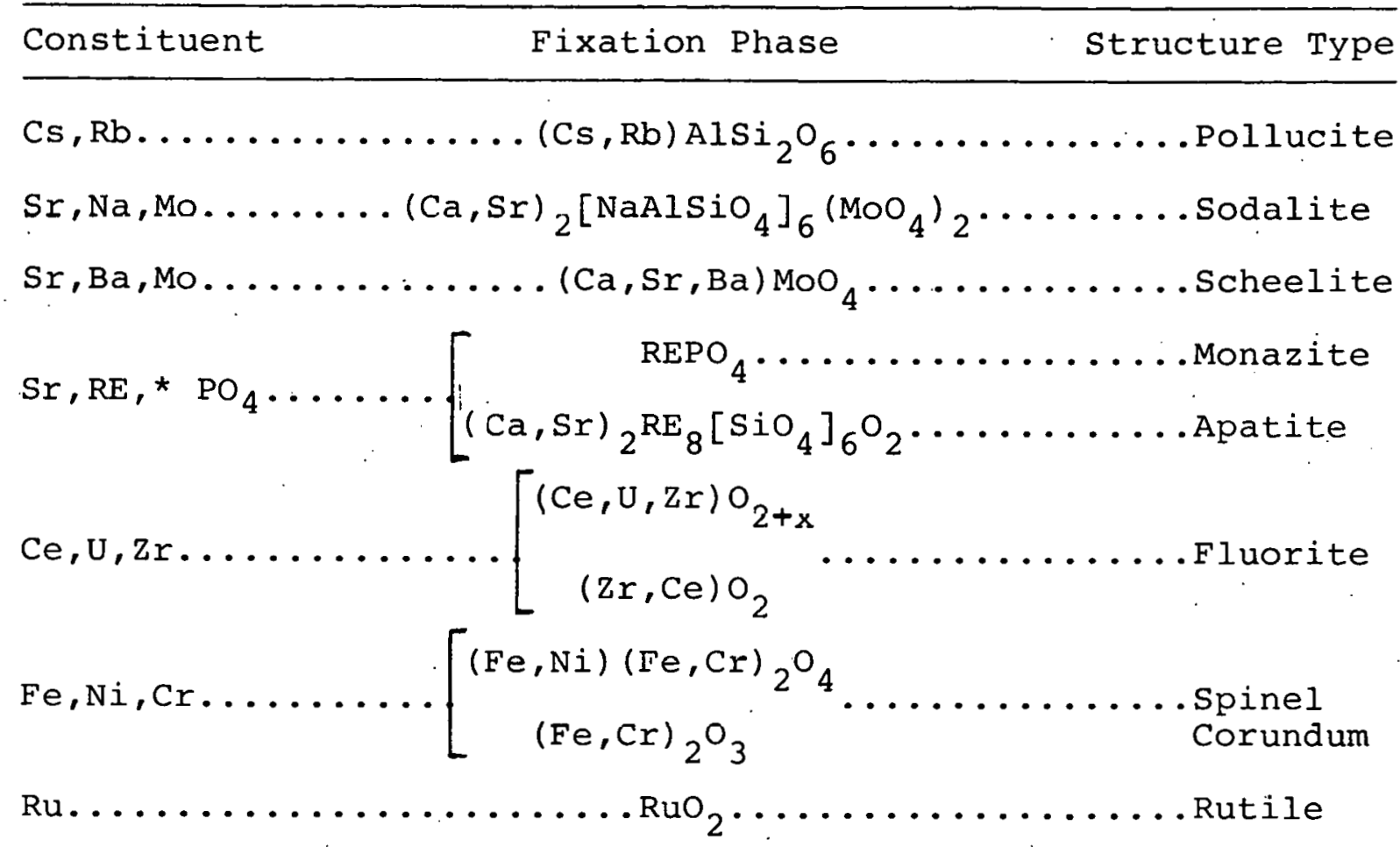

${ }^{*} \mathrm{La}, \mathrm{Pr}, \mathrm{Nd}, \mathrm{Pm}, \mathrm{Sm}, \mathrm{Eu}, \mathrm{Cd}, \mathrm{Y}$ (and probably Am, Cm). 
high-level liquid wastes. These additions give dilution by only 20 to 40 weight percent of unmodified high-level waste calcine. To date, three engineeringscale demonstrations of supercalcine preparation by spray calcination have been performed at BattelleNorthwest. Spray supercalcine is $\mathrm{X}$-ray amorphous and must be heated briefly above $950^{\circ} \mathrm{C}$ to "develop" the assemblage of crystalline phases. Reference 1 states that "if an unconsolidated calcine continues to be an acceptable waste form, supercalcine formulation concepts can be introduced into flowsheets immediately which would improve the stability and insolubility of some of the radioactive, waste constituents."

Current emphasis is on developing monolithic forms of supercalcine and recent tests of 5 to 10 millimeter spherical pellets encased in a metal matrix have been very encouraging.

The free energy state of supercalcine in-canister is not at the exact minimum as might be expected.from its definition. One reason is the structural disorder in certain supercalcine phases that is introduced by radiation and transmutation of effects. A second reason is because excess additives are included in each formulation to allow for compositional variation in the realistic high-level liquid waste streams. Thus, enough excess $A I+S i$ is added to crystallize.twice the Cs nominally present in a reprocessing plant's high-level liquid waste composition. Much of this excess alumina plus silica remains as a non-crystalline phase after the brief crystallization heat treatment and 
keeps a real supercalcine from attaining minimum free energy for its particular composition. However, it has been established that the 94 to 97 weight percent of the supercalcine product that is crystalline is in "effective" equilibrium when formed. Thus, one formulation (SPC-2) has been fired for weeks at $900^{\circ} \mathrm{C}$ without modifying the assemblage of nine compatible crystalline phases.

The specific formulation being used in our reconnaissance waste/basalt interactions studies is SPC-2. It was prepared according to McCarthy's formulation't on the spray calciner at Battelle-Northwest and crystallized by firing at $1,125^{\circ} \mathrm{C}$ for 2 to 4 hours. The crystalline phases and their shorthand notation in SPC-2 are:
$\mathrm{Ca}_{2} \mathrm{RE}_{8}\left(\mathrm{SiO}_{4}\right)_{6} \mathrm{O}_{2} \quad\left[\mathrm{~A}_{\mathrm{SSS}}\right]$
$(\mathrm{Cs}, \mathrm{Rb}, \mathrm{Na}) \mathrm{AlSi}_{2} \mathrm{O}_{6}$
[P]
$\mathrm{REPO}_{4}$
$\left[\mathrm{M}_{\mathrm{SS}}\right]$
$(\mathrm{Ce}, \mathrm{zr} \ldots)_{2}$
[F $\left.\mathrm{Fs}_{\mathrm{S}}\right]$
Tetragonal- $\mathrm{ZrO}_{2} \quad\left[\mathrm{~T}_{\mathrm{ss}}\right]$
$(\mathrm{Fe}, \mathrm{Cr})_{2} \mathrm{O}_{3}$
$\left[\left(\mathrm{Fe}_{2} \mathrm{O}_{3}\right)_{\mathrm{ss}}\right]$
$(\mathrm{Ca}, \mathrm{Sr}, \mathrm{Ba}) \mathrm{MoO}_{4}$
$\left[\mathrm{s}_{\mathrm{ss}}\right]$
$(\mathrm{Ni}, \mathrm{Fe})(\mathrm{Fe}, \mathrm{Cr})_{2} \mathrm{O}_{4}$
$\left[\mathrm{SP}_{\mathrm{SS}}\right]$

The complete composition of SPC-2 oxides is given in Table $\mathrm{V}$ and a portion of an $\mathrm{X}$-ray diffractogram of crystallized SPC is shown in Figure 2 .

It has been stated that supercalcine phases are in effective equilibrium when formed and at the temperature expected in-canister for stored high-level waste $\left(<800^{\circ} \mathrm{C}\right)$. More relevant in the context of our waste/basalt interactions studies is whether these phases will be in equilibrium with each other and with the surrounding rocks under the hydrothermal conditions which could be typical of a geologic repository. Our expectation is that some phases 


\section{TABLE V}

COMPOSITION OF SUPERCALCINE SPC-2

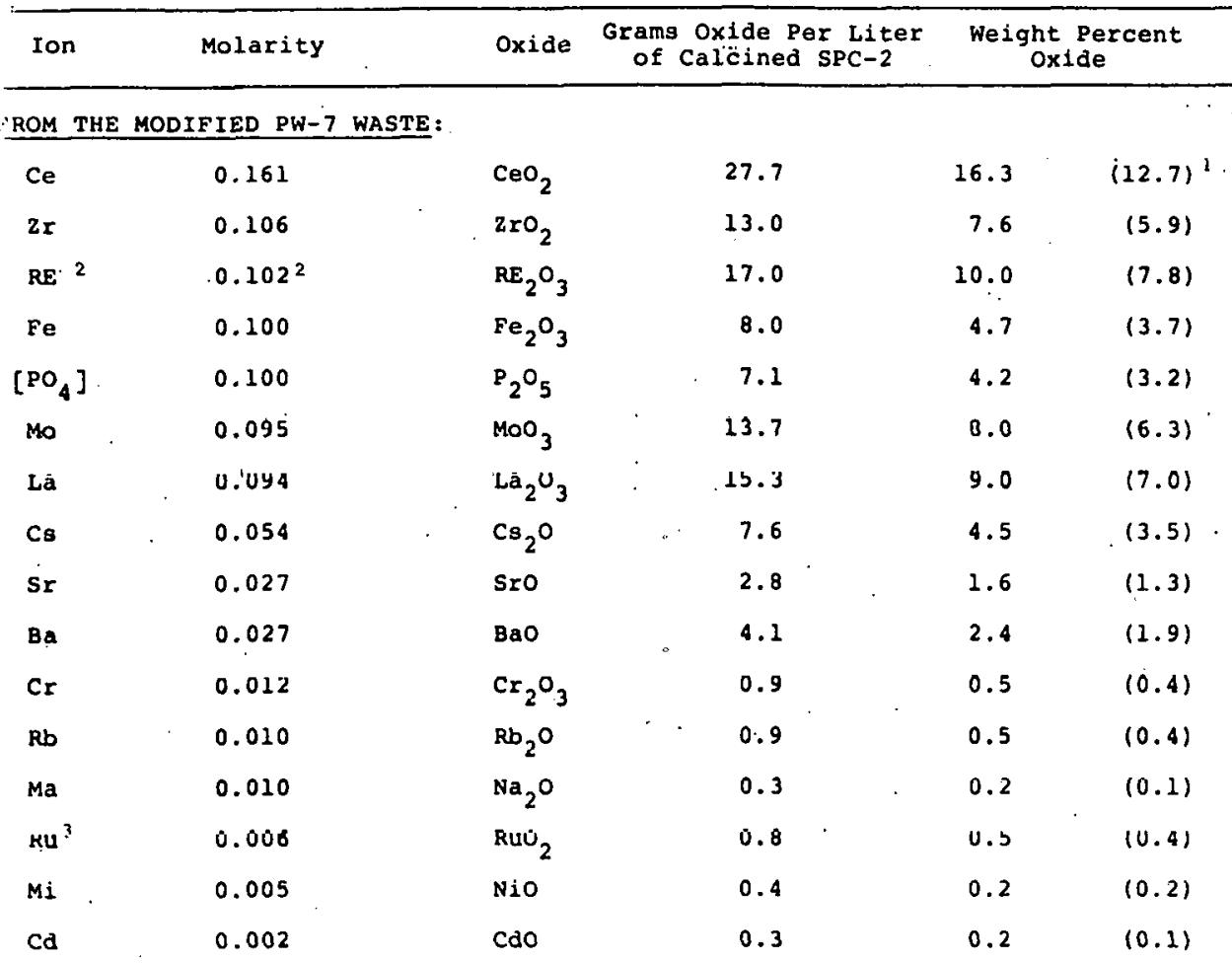

\section{SUPERCALCINE ADDITIVES:}

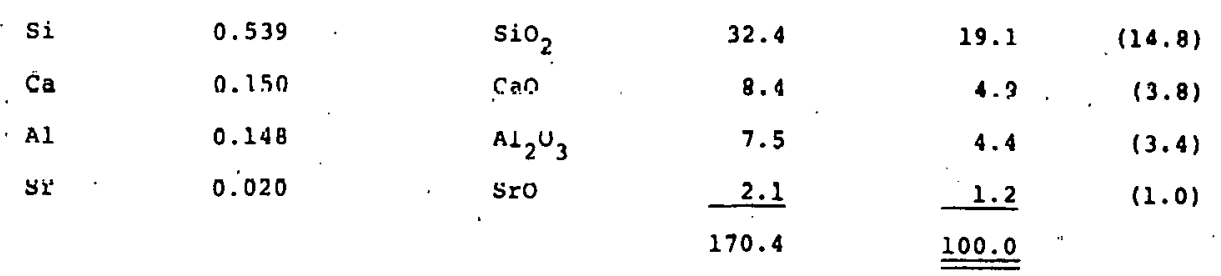

(70.5 percent waste loading)

PTHER WASTE CONETITUENTE, ${ }^{4}$

$\begin{array}{lllrlr}U(\mathrm{Pu}, \mathrm{NP}) & 0.1195 & \mathrm{U}_{3} \mathrm{O}_{\mathrm{R}} & 33.6 & & (15.5) \\ \mathrm{Ru}^{3} & 0.053 & \mathrm{RuO}_{2} & 7.1 & (3.2) \\ \mathrm{Pd} & 0.032 & \mathrm{PdO} & 3.9 & (1.8) \\ \mathrm{Te} & 0.012 & \mathrm{TOO}_{2} & 1.9 & & (0.4) \\ \mathrm{Rh} & 0.010 & \mathrm{Rh}_{2} \mathrm{O}_{3} & 1.3 & & (0.6) \\ \mathrm{Ag} & 0.002 & \mathrm{AgO} & \underline{0.3} & \underline{218.5} & \underline{100.0}\end{array}$

lValue in parentheses is the weight percent of the oxide after addition of the appropriate amounts of $\mathrm{U}, \mathrm{Ru}, \mathrm{Pd}, \mathrm{Te}, \mathrm{Rh}, \mathrm{Ag}$.

${ }^{2} \mathrm{RE}=0.061 \mathrm{Nd}+0.019 \mathrm{Pr}+0.011 \mathrm{Sm}+0.007 \mathrm{Gd}+0.003 \mathrm{Y}$ (Note: $0.002 \mathrm{RE}$ is a stand-in for $\mathrm{Am}+\mathrm{Cm})$.

${ }^{3} \mathrm{Ru}$ concentration in the spray supercalcine SPC was 10 percent of the actual PW-7 value of $0.059 \mathrm{M}$. The addition of the remaining $0.053 \mathrm{M}$ was made after calculation caloulation.

${ }^{4}$ These constituents were not included in the large batch of SPC-2 because of their expense or radioactivity. None require fixation additives. The only PW-7 conatituent not included above is TC. 


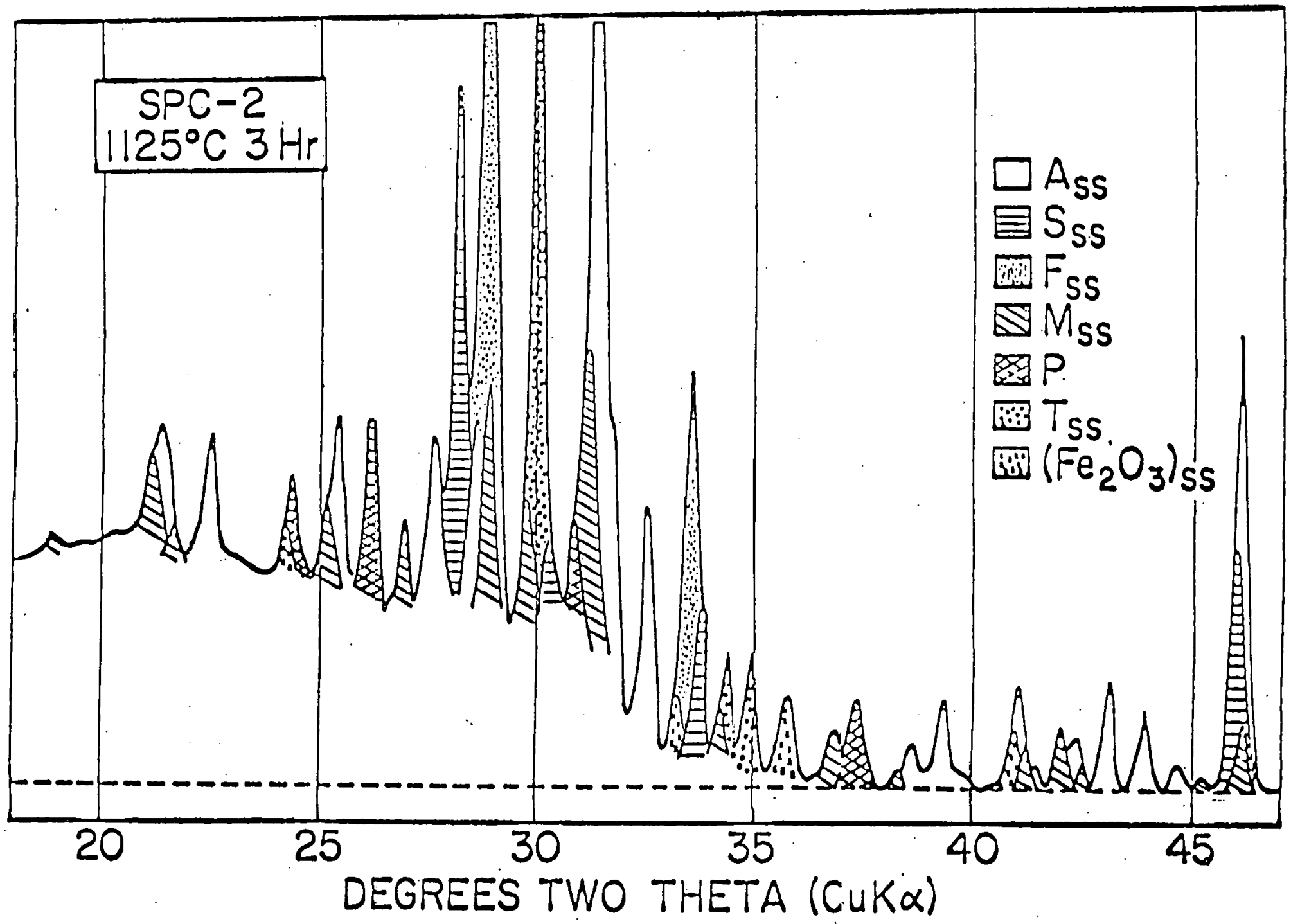

FIGURE 2

PORTION OF THE X-RAY DIFFRACTOGRAM OF SUPERCALCINE SPC-2

(The shorthand notations of the crystalline phases are explained in the text. 
will be and some will not. Many of the mineral phases listed in Table $\mathrm{V}$ are found in nature in hydrothermally formed igneous rocks. Thus, it is very likely that these minerals will be stable in hydrothermal environments at temperatures approximating their crystallization temperatures. Pollucite $\left(\mathrm{CsAlSi}_{2} \mathrm{O}_{6}\right)$, for example, is only formed in nature under hydrothermal conditions. Indeed, we would even expect pollucite to be a hydrothermal interaction product when the wastes are as reactive as calcine or glass (and, thus, readily give up their Cs) and when the rocks contain alumina and silica. Furthermore, according to the earlier discussion on reactivity of crystalline waste forms, those supercalcine crystalline phases that are not in equilibrium in the hydrothermal geologic environment would be expected to react quite slowly with any solutions.

\section{CONCLUSIONS}

Those physical and chemical factors which appear to have bearing upon the stability and/or reactivity of various radioactive wastes in contact with basalt under repository conditions have been evaluated. It is apparent from the tests that each class of waste form has unique properties which may or may not be detrimental to the concept of final storage of radioactive waste in basalt. For example, our measure of potential reactivity (the excess free energy) predicts that the most reactive of the waste forms would be calcines and the most stable waste form would be a crystaline assemblage such as spent unreprocessed fuel (see Figure 1).

The importance of the excess free energy and other factors we have discussed in the tests is obvious; they form a foundation for future laboratory evaluation 
of waste/basalt interactions for each of the waste form/basalt pairs. In other words, the waste form data themselves are no longer the major issue. Instead, we have a task with a broader scope -- to study each of the potential interactions of radioactive waste and basalt as a single system under repository conditions.

\section{ACKNOWLEDGMENTS}

The authors would like to acknowledge the assistance of Mr. W. A. Ross, Battelle-Northwest, and Dr. R. L. Gibby. Hanford Engineering Development Laboratory, in adapting Table I for this report.

We would also like to acknowledge the efforts of Dr. J. A. Apps, Lawrence Berkeley Laboratory, in reviewing the manuscript in its earliest stages.

\section{REFERENCES}

1. Battelle, Pacific Northwest Laboratories, Coordinator, Alternatives for Managing Wastes from Reactors and Post-Fission. Operations in the LWR Fuel Cycle, ERDA-76-43, U. S. Eneryy Research and Development Administration, Washington, D. C. (May 1976).

2. R. A. Deju, M. W. Grutzeck, C. W. Myers and P. A. Eddy, Environmental Factors Needed to Establish the Geotechnical Feasibility of storing Radioactive Waste in Columbia River Basalts, RHO-ST-8, Rockwell Hanford Operaliuns, Richland, Washington (September 1977).

3. J. J. Cohen, el al., Determination of Performance Criteria for High-Level Solidified Nuclear waste, NUREG-0279, U. S. Nuclear Regulatory Commission, Washington, D. C. (July 1977).

4. D. B. Hawkins and R. Roy, "Experimental Hydrothermal Sturies on Rock. Alteration and Clay Mineral Formation," Geochim. Cosochim. Acta, 27, 1047-1054 (1963): 
5. R. Roy, "Aids in Hydrothermal Experimentation, II, J. Amer. Ceram. Soc., 39, 145-146 (1956).

6. J. E. Mendel, et al., Annual Report on the Characteristics of High-Level waste Glasses, BNwL-2252, Battelle, Pacific Northwest Laboratories, Richland, Washington (1977).

7. Y. B. Katayama, Leaching of Irradiated LWR Fuel Pellets in Deionized and Typical Groundwater, BNWL-2057, BatteIle, Pacific Northwest Laboratories, Richland, Washington (1976).

8. G. J. McCarthy and M. T. Davidson, "Ceramic Nuclear Waste Forms: I. Crystal Chemistry and Phase Formation in Calcine," Amer. Ceram. Soc. Bull., 54, 782-786 (1975).

9. J. E. Mendel and J. L. McElroy, Waste Solidification Program, Volume 10, Evaluation of Solidified Products, BNWL-1666, Battelle, Pacific Northwest Laboratories, Richland, Washington (1972).

10. R. P. Turcotte and J.W. Wald, Quarterly Progress Report, Waste Fixation Program, BNWL-2242, Battelle, Pacific Northwest Laboratories, Richland, washington (1977).

11. G. J. McCarthy, M. T. Davidson, D. E. Pfoertsch, C. A. Smith, S. A. Gallagher, and R. G. Johnston, "Oxide Ceramic Nuclear Waste Forms," Amer. Ceram. Soc. Bull., 54, 459 (1975).

12. G. J. McCarthy, "High Level Waste Ceramics: Materials Considerations, Process Simulation and Product Characterization," Nucl. Technol., 32, 92-105 (1977).

13. G. J. McCarthy, "Ceramics and Glass Ceramics as High Level Waste Forms," Ceramic and Glass Radioactive Waste Forms, D. W. Readey and C. R. Cooley, Editors, CONF-770102, U. S.' Energy Research and Development Administration, Washington, D. C. (April 1977).

14. G. J. McCarthy, Advanced Waste Forms Research and Development. Comprehensive Progress Report, co0-2510-12, 'The Pennsylvania State University, University Park, Pennsylvania (1977). 


\section{DISTRIBUTION}

Number of Copies

1

1

1

1

1

6

1

1

1

1

2

1

2

1

3

3

\section{ALLIED CHEMICAL CORPORATION}

B. R. Dickey

ATOMIC ENERGY OF CANADA, LTD.

T. E. RummerY

ATOMICS INTERNATIONAL

R. B. Paulson

ARGONNE NATIONAL LABORATORY

A. M. Friedmán

BATTELLE COLUMBUS LABORATORIES

J. Batch

BATTFITITF-NORTHWEST

D. J. Bradley

W. A. Ross

R. J. Serne (3)

J. A. Stottlemyre

BROOKHAVEIJ NATIONAL LABORATORY

P. W. LevY

CORNING GLASS WORKS

M. G. Britton

ELECTRIC POWER RESEARCH INSTITUTE

R. F. Williams

GEORGIA INSTITUTE OF TECHNOLOGY

C. E. Weaver

HAHN-MEITNER INSTITUTE

H. W. Levi

W. Lutze

INSTITUTE FOR CHEMICAL TECHNOLOGY

E. R. Merz

INTERNATIONAL ATOMIC ENERGY AGENCY

KFA-KERFORSCHUNGSANL $\Lambda \mathrm{CE}$

LAWRENCE BERKELEY LABORATORY

J. A. Apps

IAAWRENCE LIVERMORE LABORATORY

I. B. Ballou

A. G. Duba

L. D. Ramspott 


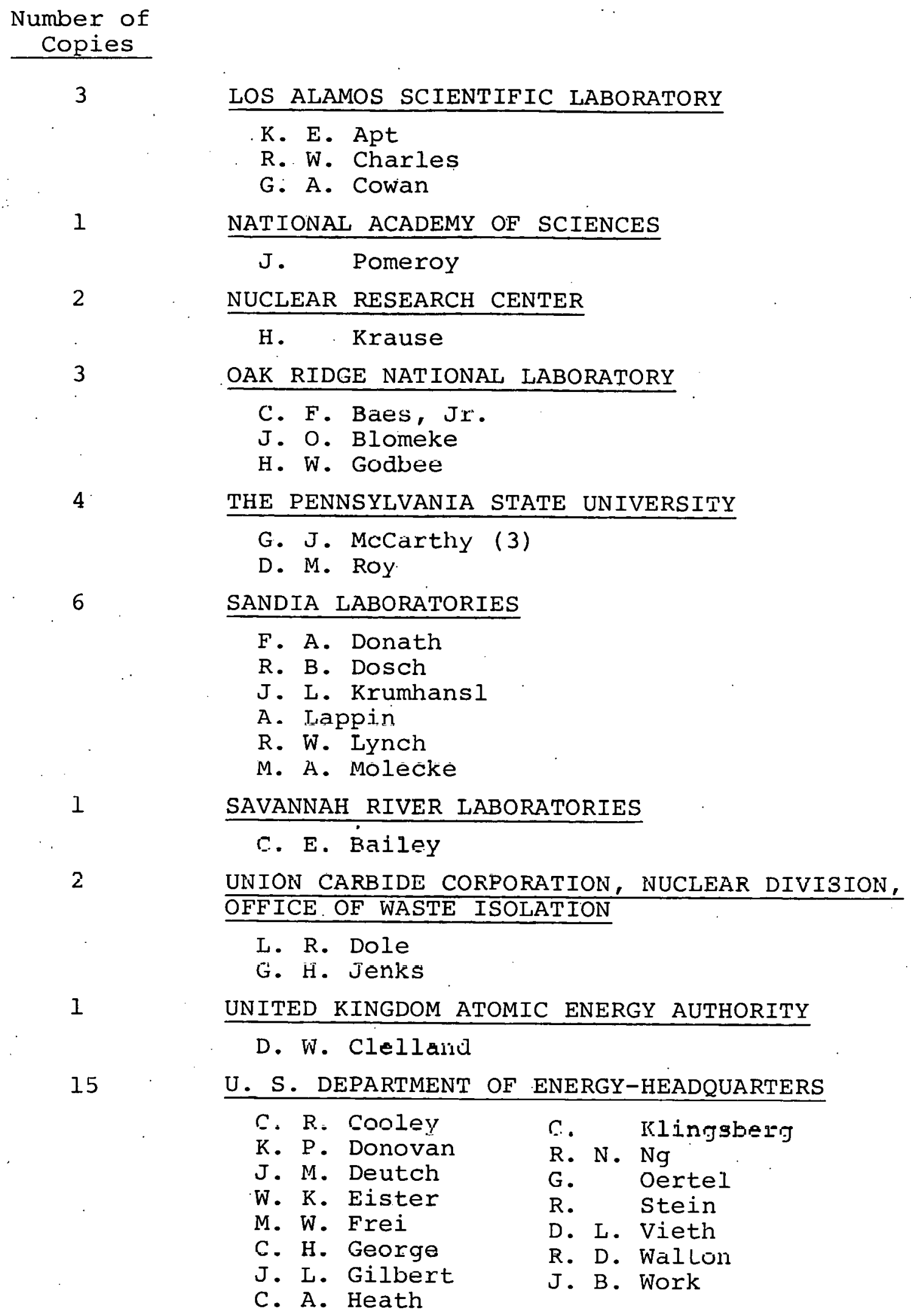




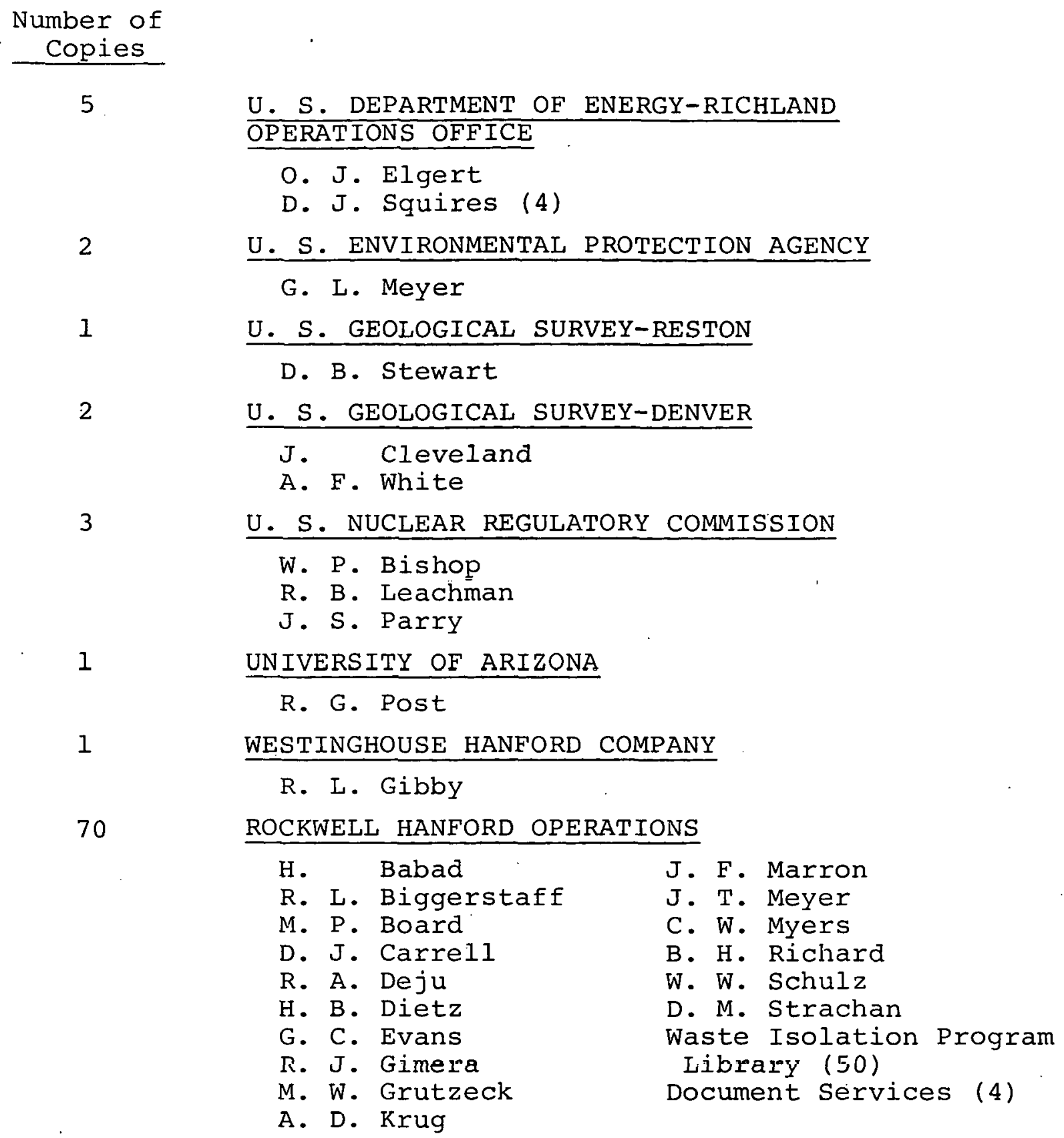

